\title{
Front Matter: Volume 7170
}

, "Front Matter: Volume 7170," Proc. SPIE 7170, Design and Quality for Biomedical Technologies II, 717001 (6 March 2009); doi: 10.1117/12.827225

SPIE. Event: SPIE BiOS, 2009, San Jose, California, United States 
PROGRESS IN BIOMEDICAL OPTICS AND IMAGING

Vol. 10 , No. 10

\section{Design and Quality for Biomedical Technologies II}

Ramesh Raghavachari

Rongguang Liang

Editors

26 January 2009

San Jose, California, United States

Sponsored and Published by

SPIE

Volume 7170

Proceedings of SPIE, 1605-7422, v. 7170

SPIE is an international society advancing an interdisciplinary approach to the science and application of light. 
The papers included in this volume were part of the technical conference cited on the cover and title page. Papers were selected and subject to review by the editors and conference program committee. Some conference presentations may not be available for publication. The papers published in these proceedings reflect the work and thoughts of the authors and are published herein as submitted. The publisher is not responsible for the validity of the information or for any outcomes resulting from reliance thereon.

Please use the following format to cite material from this book:

Author(s), "Title of Paper," in Design and Quality for Biomedical Technologies II, edited by Ramesh Raghavachari, Rongguang Liang, Proceedings of SPIE Vol. 7170 (SPIE, Bellingham, WA, 2009) Article CID Number.

ISSN 1605-7422

ISBN 9780819474162

Published by

SPIE

P.O. Box 10, Bellingham, Washington 98227-0010 USA

Telephone +1 3606763290 (Pacific Time) · Fax +1 3606471445

SPIE.org

Copyright (C) 2009, Society of Photo-Optical Instrumentation Engineers.

Copying of material in this book for internal or personal use, or for the internal or personal use of specific clients, beyond the fair use provisions granted by the U.S. Copyright Law is authorized by SPIE subject to payment of copying fees. The Transactional Reporting Service base fee for this volume is $\$ 18.00$ per article (or portion thereof), which should be paid directly to the Copyright Clearance Center (CCC), 222 Rosewood Drive, Danvers, MA 01923. Payment may also be made electronically through CCC Online at copyright.com. Other copying for republication, resale, advertising or promotion, or any form of systematic or multiple reproduction of any material in this book is prohibited except with permission in writing from the publisher. The CCC fee code is 1605 $7422 / 09 / \$ 18.00$.

Printed in the United States of America.

Publication of record for individual papers is online in the SPIE Digital Library.

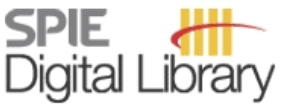

SPIEDigitallibrary.org

Paper Numbering: Proceedings of SPIE follow an e-First publication model, with papers published first online and then in print and on CD-ROM. Papers are published as they are submitted and meet publication criteria. A unique, consistent, permanent citation identifier (CID) number is assigned to each article at the time of the first publication. Utilization of CIDs allows articles to be fully citable as soon they are published online, and connects the same identifier to all online, print, and electronic versions of the publication. SPIE uses a six-digit CID article numbering system in which:

- The first four digits correspond to the SPIE volume number.

- The last two digits indicate publication order within the volume using a Base 36 numbering system employing both numerals and letters. These two-number sets start with $00,01,02,03,04$, $05,06,07,08,09,0 A, 0 B \ldots$. 0Z, followed by 10-1Z, 20-2Z, etc.

The CID number appears on each page of the manuscript. The complete citation is used on the first page, and an abbreviated version on subsequent pages. Numbers in the index correspond to the last two digits of the six-digit CID number. 


\section{Contents}

vii Conference Committee

\section{SESSION 1 DESIGN OF BIOMEDICAL TECHNOLOGIES}

717003 A novel concept for protein microarray: land-contrast BioCD [7170-02]

X. Wang, M. Zhao, D. D. Nolte, Purdue Univ. (United States)

717004 Dual-reference full-range frequency domain optical coherence tomography [7170-31]

K.-S. Lee, P. Meemon, CREOL, College of Optics \& Photonics, Univ. of Central Florida (United States); K. Hsu, Micron Optics, Inc. (United States); W. J. Dallas, College of Optical Sciences, The Univ. of Arizona (United States); J. P. Rolland, Institute of Optics, Univ. of Rochester (United States)

717006 Development of a remote photoplethysmographic technique for human biometrics [7170-04]

P. Shi, Loughborough Univ. (United Kingdom) and Shanghai Jiao Tong Univ. (China); S. Hu, A. Echiadis, V. Azorin Peris, J. Zheng, Loughborough Univ. (United Kingdom); Y. Zhu,

Shanghai Jiao Tong Univ. (China)

\section{SESSION 2 DESIGN OF IMAGING SYSTEMS}

717008 A novel fast imaging modality for free radicals in vivo: continuous wave (CW) EPR imaging with direct detection and rapid field scan in the presence of rotating gradients (Keynote Paper) [7170-06]

S. Subramanian, J. W. Koscielniak, N. Devasahayam, National Institutes of Health (United States); G. Salem, R. H. Pursley, T. J. Pohida, SAIC-Frederick NCl Cancer Research and Development Ctr. (United States); M. C. Krishna, National Institutes of Health (United States)

717009 Quantification of resolution for a dynamic focusing OCM microscope [7170-30]

S. Murali, CREOL, College of Optics \& Photonics, Univ. of Central Florida (United States); K. S. Lee, Institute of Optics, Univ. of Rochester (United States); P. Meemon, CREOL, College of Optics \& Photonics, Univ. of Central Florida (United States); W. P. Kuhn, Opt-E (United States); K. P. Thompson, Optical Research Associates (United States); J. P. Rolland, Institute of Optics, Univ. of Rochester (United States)

7170 OA Design of reflectance confocal microscopes for clinical applications (Invited Paper) [7170-08]

J. M. Zavislan, Institute of Optics, Univ. of Rochester (United States)

7170 OB Integrated biophotonics in endoscopic oncology [7170-09]

N. Muguruma, St. Michael's Hospital (Canada); R. S. DaCosta, B. C. Wilson, Ontario Cancer Institute (Canada); N. E. Marcon, St. Michael's Hospital (Canada) 
$71700 \mathrm{C}$ Hyperspectral imaging utilizing LCTF and DLP technology for surgical and clinical applications (Invited Paper) [7170-10]

K. J. Zuzak, R. P. Francis, E. F. Wehner, The Univ. of Texas at Arlington (United States); J. Smith, Texas Instruments (United States); M. Litorja, D. W. Allen, National Institute of Standards and Technology (United States); C. Tracy, J. Cadeddu, E. Livingston, University of Texas Southwestern Medical Ctr. (United States)

\section{SESSION 3 QUALITY OF CLINICAL SYSTEMS}

7170 OF Development and validation of a system based on spectral-photometry for measuring fluid dynamics of multi-infusion conditions in intensive care units [7170-13]

A. Timmerman, B. Riphagen, J. Klaessens, R. Verdaasdonk, Univ. Medical Ctr. Utrecht (Netherlands)

\section{SESSION 4 QUALITY OF COMPONENTS}

7170 OG Calibrating fluorometers for clinical diagnostics [7170-14]

E. Heinz, Heinz Optical Engineering, LLC (United States)

$7170 \mathrm{OH} \quad$ Securing quality of camera-based biomedical optics [7170-15]

F. Guse, A. Kasper, LINOS Photonics GmbH \& Co. KG (Germany); B. Zinter, Qioptiq LINOS, Inc. (United States)

7170 ol Evaluation of a reflectance-based approach for optical property determination in layered tissue [7170-16]

Q. Wang, U.S. Food and Drug Administration (United States) and Univ. of Maryland, College Park (United States); A. Agrawal, U.S. Food and Drug Administration (United States);

N. S. Wang, Univ. of Maryland, College Park (United States); J. Pfefer, U.S. Food and Drug Administration (United States)

\section{SESSION 5 BIOMEDICAL TECHNOLOGIES}

7170 0J Full field laser Doppler flowmetry with custom made CMOS sensors [7170-17]

D. He, N. Hoang, B. R. Hayes-Gill, J. A. Crowe, Y. Zhu, S. P. Morgan, The Univ. of Nottingham (United Kingdom)

7170 OK Fast-gated single-photon avalanche diode for extremely wide dynamic-range applications [7170-18]

A. Tosi, A. Dalla Mora, F. Zappa, S. Cova, D. Contini, A. Pifferi, L. Spinelli, A. Torricelli,

R. Cubeddu, Politecnico di Milano (Italy)

$7170 \mathrm{OL}$ Pseudo-random single photon counting: the principle, simulation, and experimental results [7170-19]

Q. Zhang, N. G. Chen, National Univ. of Singapore (Singapore) 


\section{SESSION 6 COMPONENTS}

$71700 \mathrm{M} \quad$ New lighting for the design of high quality biomedical devices [7170-20]

C. B. Jaffe, S. M. Jaffe, A. R. Conner, Lumencor, Inc. (United States)

7170 ON Source stabilization for high quality time-domain diffuse optical tomography [7170-21]

W. Mo, N. Chen, National Univ. of Singapore (Singapore)

717000 Tolerancing fluorometers for in vitro diagnostics [7170-22]

E. Heinz, Heinz Optical Engineering, LLC (United States)

Author Index 
Downloaded From: https://www.spiedigitallibrary.org/conference-proceedings-of-spie on 26 Apr 2023

Terms of Use: https://www.spiedigitallibrary.org/terms-of-use 


\title{
Conference Committee
}

\author{
Symposium Chairs \\ James G. Fujimoto, Massachusetts Institute of Technology (United \\ States) \\ R. Rox Anderson, Wellman Center for Photomedicine, Massachusetts \\ General Hospital (United States) and Harvard School of Medicine \\ (United States)
}

Program Track Chairs

Tuan Vo-Dinh, Duke University (United States)

Anita Mahadevan-Jansen, Vanderbilt University (United States)

Conference Chairs

Ramesh Raghavachari, U.S. Food and Drug Administration (United States)

Rongguang Liang, Carestream Health, Inc. (United States)

Conference Cochair

T. Joshua Pfefer, U.S. Food and Drug Administration (United States)

Program Committee

Anthony Joseph Durkin, Beckman Laser Institute and Medical Clinic (United States)

Kazuhiro Gono, Olympus Corporation (Japan)

Jeeseong Hwang, National Institute of Standards and Technology (United States)

Steve P. Morgan, The University of Nottingham (United Kingdom)

Jannick P. Rolland, College of Optics and Photonics, University of Central Florida (United States)

Rudolf M. Verdaasdonk, Universitair Medisch Centrum Utrecht (Netherlands) 


\section{Session Chairs}

1 Design of Biomedical Technologies

Ramesh Raghavachari, U.S. Food and Drug Administration (United States)

Jannick P. Rolland, College of Optics and Photonics, University of Central Florida (United States)

2 Design of Imaging Systems

Ramesh Raghavachari, U.S. Food and Drug Administration (United States)

Rongguang Liang, Carestream Health, Inc. (United States)

3 Quality of Clinical Systems

Stephen P. Morgan, The University of Nottingham (United Kingdom)

$4 \quad$ Quality of Components

Rudolf M. Verdaasdonk, Universitair Medisch Centrum Utrecht (Netherlands)

5 Biomedical Technologies

Anthony Joseph Durkin, Beckman Laser Institute and Medical Clinic (United States)

6 Components

Anthony Joseph Durkin, Beckman Laser Institute and Medical Clinic (United States)

Poster Session

Kazuhiro Gono, Olympus Corporation (Japan) 